\title{
Investigation of Rice Husk Ash (RHA) as a Supplement in Cement for Building Applications
}

\author{
Emmanuel B Ettah ${ }^{1}$, Jerome G Egbe ${ }^{2 *}$, Emmanuel S Ubi ${ }^{2}$ and Ekei E Okon ${ }^{2}$ \\ ${ }^{1}$ Physics department, Cross River University of Technology, Nigeria \\ ${ }^{2}$ Civil Engineering department, Cross River University of Technology, Nigeria
}

Submission: June 09, 2018; Published: July 20, 2018

*Corresponding author: Jerome Egbe, Civil Engineering department, Cross River University of Technology, Calabar, Nigeria, Email: jeromelina2011@yahoo.com

\begin{abstract}
An investigation of Rice husk ash Pozzolan as a supplement in cement for building applications was carried out. A controlled burning of rice husk ash (RHA) at 5000C produced amorphous Silica (SiO2). The rice husk ash (RHA) was substituted for cement in proportions of $0 \%, 5 \%, 10 \%$, $20 \%$ and $30 \%$ of concrete. The concrete was cured for 7 days, 14 days, 21 days and 28 days respectively. It was observed that $20 \%$ replacement of Rice husk ash (RHA) provides the optimum strength. Comparison of mixtures with particle sizes of 600 microns, 425 microns, 300 microns, 212 microns, 150 microns and 75 microns, showed that 75 microns provide the optimum strength. X-ray fluorescence (XRF) analysis was performed to determine the content of various chemical oxides in RHA, which indicated that Mg 0.9\%, Si 81.8\%, P 5.48\%, K 3.19\%, Ca $1.80 \%$, Mn $0.417 \%$, Fe $0.782 \%$, Zn $0.140 \%$ and Ru $0.270 \%$. X-ray diffraction (XRD) analysis to determine low crystallinity of the samples showed the peak value at 26.66 known to be the quartz primary.
\end{abstract}

Keywords: Amorphous; Building; Cement;Concrete;Micron; Pozzolan;Rice Husk

Abbreviations: RHA: Rice Husk Ash; XRF: X-ray Fluorescence; XRD:X-ray Diffraction; OPC: Ordinary Portland Cement; SP: Superplasticizer; PCR: Partial Cement Replacement; INAA: Instrumental Neutron Activation Analysis; ASIM: America Society for Testing and Materials; LPC: LimePozzolan Cement

\section{Introduction}

The utilization of pozzolanic materials in cement and concrete manufacturing has increased significantly. RHA is an agro waste product and it indicates a high amount of silica which is a very good value for workability. Rice husks are the natural sheaths that form on rice grains during their growth; these are removed during the milling of rice, although these seem to have no commercial interest. However, it can be made useful through a variety of thermochemical conversion processes [1].

In the majority of rice producing Countries, most of the husks produced from the processing of rice are either burnt or dumped as a waste. Rice husk is unusually high in ash compared to other biomass fuels; it has close to $20 \%$ of ash as a by-product [2]. Ash is $92-95 \%$ silica, highly porous and lightweight, with an external surface area. So with large ash content and silica content in the ash, it becomes economical to extract silica from ash which takes care of ash disposal [2]. The ideal temperature for producing RHA is between 6000 to 7000 S. Patil and B. Patil [3]. Rice husk ash (RHA) is a term describing all types of ash produced from burning rice husks which vary considerably according to burning techniques. According to [4]. The silica in the ash undergoes structural transformations depending on conditions such as time and temperature of combustion. At 5000C to 7000C amorphous ash is formed and at a temperature greater than this, crystalline ash is formed [5]. These types of silica have different properties and it is important to produce ash of the correct specification for the particular end use. Despite the importance of rice husk ash, few academic studies have been carried out in Nigeria to find the elemental content of the ash using Neutron Activation Analysis Technique X-ray diffraction analysis to determine the atomic and molecular structure of the compounds in the ash. The applicability of the X-ray fluorescence to determine the concentration of the chemical elements and the thermal conductivity test is to determine the insulating properties of the material.

Pozzolans are materials containing reactive silica and alumina which on their own have little or no binding property but when mixed with lime in the presence of water, will set and harden like cement.

Furthermore, pozzolans are important addictive aggregates in the production of alternative cementing materials to ordinary Portland Cement (OPC). Alternative blocks of cement provide 
an excellent technical option to OPC at a much lower cost and have the potential to make a significant contribution towards the provision of low-cost building materials and consequently, affordable shelter.

According to he discussed that; Pozzolans can be used in combination with lime and OPC, he further stresses that the Pozzolans will greatly improve the properties of lime-based mortars, concretes and renders suitably for use in a wide or range of building applications. Alternatively, they can be blended with OPC to improve the durability of concrete and its workability, and considerably reduce its cost, According to Cook and Vienna.

However, Ghassan and Hilmi, focused on the study of rice husk ash and its uses as a cement replacement material and investigated the properties of rice husk ash (RHA) produced by using a Ferrocement furnace. The XRD analysis has been extensively been used in conducting and verifying the presence of amorphous silica in the ash. Furthermore, the average particle size and percentage on concrete workability, fresh density, superplasticizer (SP) content and the compressive strength were also studied. The concluded that RHA concrete gave an excellent improvement in strength for $10 \%$ replacement $30.8 \%$ increment compared to the control mix), and up to $20 \%$ of cement could be valuable replaced with RHA without adversely affecting the strength.

Kartini et al, [6], rice husk ash pozzolanic material for sustainability]. An intensive study on RHA was conducted to determine its suitably from the various grade of concrete (Grade $30,40,50)$ studied. In their conclusion it was revealed that up to $30 \%$ replacement of OPC with RHA has the potential to be used as partial cement replacement (PCR), having good compressive strength performance and durability, thus have the potential of using RHA as PCR material and this can contribute to sustainable construction.

Sudisht et al, discuss the effect of rice husk ash on cement mortar and concrete. They find out that workability compressive strength and durability are three basic properties of concrete. They concluded that reduction in water absorption, from results obtained from six test concrete and three tests on mortar sample, was observed that up to 10\% RHA with concrete and mortar enhances all properties and it is observed that $12.5 \%$ of Rice Husk Ash by mass of cement as the optimum are to be added in the concrete production M20 particularly when the husk is burnt under field condition to utilize the easily available and low-cost resources for betterment of concrete structure with respect to economy, durability and strength.

Patnaikuni, et al. coined out studies on the determination of compressive strength of different grades of rice husk ash-an Ecofriendly concrete and has evolved as an innovative technology, capable of achieving the status of being an outstanding advancement in the sphere of concrete technology. The investigated that the utilization of rice husk ash (RHA) will reduce the dumping of rice husk as well as reduce the construction cost.
Investigation for the determination of residual compressive strength of M30 and 40 grades of RHA concretes exposed at different temperature were carried out almost all specimens of M30 and 40 grades of RHA concrete and normal concrete exhibited zero strength at a temperature of $10000 \mathrm{C}$. It shows that concrete cannot withstand a temperature of $10000 \mathrm{C}$ and above. The concluded that compressive strength of RHA concrete was higher at a temperature below $5000 \mathrm{C}$ and decreases above $5000 \mathrm{C}$.

Omotola carried out an investigation on instrumental analysis of rice husk ash. He finally showed that rice husk ash (RHA) is one of the most silica raw materials containing about $90-98 \%$ silica after complete combustion among the family of other agro-wastes. Ash samples from rice husks of five origins were prepared at two different temperatures, 5000C and 10000C respectively and the ash content evaluated at each temperature. X-Ray Diffraction (XRD), X-Ray Fluorescence (XFR), Instrumental Neutron Activation Analysis (INAA) alongside with a simple chemical process were the techniques adopted for the characterization of each ash sample heated to $10000 \mathrm{C}$ in terms of silica content. While XRD analysis indicates the compounds present in each sample, XRF and INAA analysis indicate only trace (impurity) elements present in each ash sample. He concluded that XRF and INAA showed that RHA had a very low impurity concentration indicating that rice husk which is an agricultural waste is a potential source of silica, and the result was confirmed by the XRD analysis where almost all the compounds presents where silicates and the simple chemical process employed confirmed the very high silica presence of between 93-96\%, and the XRF result shows a high purity level of 94-98.9\% while the INAA shows a purity level of $88.4 \%$.

Omotola \& Onojah[7], in their research work they reported that the potentiality of rice husk is a good source of high technological materials. That every year approximately 600 million tons of paddy are produced globally. These give around 120 million tons of rice husk (RH) and 21 million tons of rice husk ash (RHA) annually. There are four major uses of rice husk ash: in steel, cement, refractory bricks and semiconductor industry. Besides these, it can be utilized in many civil construction works. The concluded that the use of rice husk for electricity generation in an efficient manner is likely to transform this agricultural waste into a valuable fuel for industries and thus help in boosting the farm economy and rural development and at the same time, waste disposal of rice husk is addressed while generation of employment will become possible.

\section{Materials and Method}

The materials used in this work were rice husk, burning furnace, hammer mill, sieve machine, mortal and weight balance. Ground granulated blast furnace slag and RHH were used in this research as components. The (America society for testing and materials (ASIM) Type I) was used to compare the different properties including physical, chemical binding, flow and compressive strength were collected from local stations in Obubra, 
Ogoja, and Bekwara Local Government Areas in Cross River State, known to be major rice producers in Cross River State Nigeria, the Ikom-Abi river sand which passed through a $4.75 \mathrm{~mm}$ sieve and had a specific gravity of about 2.89 was used as fine aggregate $\mathrm{x}$-ray fluorescene (XRF) was done for the chemical composition using a Bruker brand XRF machine. The Abrasion machine was used grinding of the RHA; the detailsof the furnace were reported by Zain etal.

\section{Mathematical formulation for RHA strength correction factor}

$$
e=(W / R) /(W / C)
$$

Where, W/R is the water / RHA cement ratio, W/C is the water / cement ratio which gives the strength as that of $\mathrm{W} / \mathrm{R}$ ratio. The value of e can be obtained by routines laboratory tests.

The equation 2.2 can be applied to all pozzolanic materials and it can be used to relate the strength of RHA concrete to that of OPC concrete having the same $\mathrm{W} / \mathrm{C}$ ratio and values of e can be obtained from the plotted RHA and OPC concrete, Nelson S [8].

$$
\begin{aligned}
& W_{C}=S_{C}+L C_{C}+L A_{C} \\
& \text { and } W_{T}=S_{F}+L C_{T}+L A_{T}
\end{aligned}
$$

By rearranging these equations, we have general form

$$
f=\left(w_{C}-w_{T}+S_{T}-C_{C}\right) / C
$$

Where, $w_{C}$ is the free water content, $S_{T}$ and $S_{C}$ are the weights of water required to provide the standard consistence of the RHA cement and OPC respectively. The $\mathrm{f}$ is the proposed design parameter that can be obtained by routine laboratory tests [9-13].

The amount of free water for lubrication of aggregate is given below:

$$
L C_{r}+L A_{T}=W_{T}-S_{T}
$$

Results

Table 2: Chemical Properties of Materials.

\begin{tabular}{|c|c|c|c|c|c|c|c|c|c|c|c|}
\hline \multicolumn{10}{|c|}{ Chemical Properties, Oxide Composition (\%) } \\
\hline & $\mathbf{S i O}_{\mathbf{2}}$ & $\mathbf{A I}_{2} \mathbf{O}_{\mathbf{3}}$ & $\mathbf{F e}_{\mathbf{2}} \mathbf{O}_{\mathbf{3}}$ & $\mathbf{C}_{\mathbf{9 0}}$ & $\mathbf{M g 0}$ & $\mathbf{S O}_{\mathbf{3}}$ & $\mathbf{N a}_{\mathbf{2}} \mathbf{0}$ & $\mathbf{K}_{\mathbf{2}} \mathbf{0}$ & $\mathbf{P}_{\mathbf{2 0 5}}$ & $\mathbf{T}_{\mathbf{1}} \mathbf{O}_{\mathbf{2}}$ & $\mathbf{Z n O}_{\mathbf{2}}$ \\
\hline $\mathrm{RHA}$ & 81.8 & 0.38 & 0.78 & 1.8 & 0.9 & 0.56 & 0.05 & 3.1 & 5.4 & 0.02 & 0.14 \\
\hline OPC & 20.99 & 4.6 & 4.44 & 67.17 & 2.53 & 2.98 & 0.03 & 0.16 & & & 1.3 \\
\hline
\end{tabular}

The rice husk ash (RHA) heated at temperature of $5000 \mathrm{C}$ were analyzed with x-ray fluorescence (XRF) analysis, indicating the compounds present in the sample: $\mathrm{Mg}, \mathrm{Si}, \mathrm{P}, \mathrm{K}, \mathrm{Ca}, \mathrm{Ti}, \mathrm{Cr}, \mathrm{Mn}, \mathrm{Fe}, \mathrm{Ni}$, $\mathrm{Cu}, \mathrm{Zn}, \mathrm{Rb}, \mathrm{Sr}, \mathrm{Y}, \mathrm{Zr}, \mathrm{Ba}$ and Eu. From the test carried out, it revealed that Si contains the highest percentage of silica with $81.8 \%$ with the x-ray diffraction (XRD) analysis also showing the presence of $\mathrm{SiO}_{2}$ as an amorphous silica. The peak value at 26.66 known to be quartz primary is weak thus a low level of crystallization. See
Where, $L A_{T}=$ free water content for lubrication of aggregate,

$$
\begin{aligned}
& L C_{r}=\text { free water content for lubrication of RHA } \\
& W_{T}=\text { free water content of the RHA concrete } \\
& S_{T}=\text { weight of water required to achieve standard }
\end{aligned}
$$
consistence of RHA cement (Table 1).

Table 1: Sources of Rice Husk Samples.

\begin{tabular}{|c|c|c|}
\hline Sample & Location & Place \\
\hline 1 & Obubra & Inyamayong \\
\hline 2 & Ogoja & Bansara \\
\hline 3 & Bekwara & Ukporo \\
\hline
\end{tabular}

\section{Ash and Concrete Production}

The husks were properly burned for the voltaic hydrocarbon to escape, the husk was poured into crucibles which were placed The ash obtained at this temperature was allowed to cool in the muffle furnace for some hours and with the use of forceps and content of the crucibles were transferred into a pan $[14,15]$.

The paste and mortar were prepared according to ASTM C305-06 specification. The compaction of the mold was achieved manually. Finally, samples were immersed into a curing tank at room temperature until the desired testing ages of 7, 14, 21 and 28 days were achieved.

The RHA was ground into a fine powder, hammer mill was used for this purpose, and was sieve with different sieve sizes, with the help of a sieving machine of the aperture of 600 microns, 425 microns, 300 microns, 212 microns, 150 microns and 75 microns, and this becomes our pozzolans, $0 \%, 5 \%, 10 \%, 20 \%$, and $30 \%$ ratio of the pozzolanic were mixed with part of cement and laterite, were cast and cured for 7 days, 14 days, 21 days and 28 days, and tested with the help of a compression testing machine to know the optimum strength [16]. in the muffle furssnace for combustion to a temperature of $500^{\circ} \mathrm{C}$.

Table 2 for the chemical properties of the materials.

\section{Strength at various dortices size}

The result of the different mixed ratio of portees at 75 microns, 150 microns, 212 microns, 300 microns, 425 microns and 600 microns, cast and cured for 7 days, 14 days, 21 days and 28 days. It was tested with the help of a compression test machine shown in Table 3 below [17]. 


\section{Civil Engineering Research Journal}

Table 3: Mixed Ratio of Different Micron.

\begin{tabular}{|c|c|c|c|c|c|c|}
\hline No. of Days & $\begin{array}{l}\text { Strength at } 75 \\
\quad \text { Micron }\end{array}$ & $\begin{array}{l}\text { Strength at } 150 \\
\text { Micron }\end{array}$ & $\begin{array}{c}\text { Strength at } 212 \\
\text { Micron }\end{array}$ & $\begin{array}{c}\text { Strength at } 300 \\
\text { Micron }\end{array}$ & $\begin{array}{c}\text { Strength at } 425 \\
\text { Micron }\end{array}$ & $\begin{array}{l}\text { Strength at } 600 \\
\text { Micron }\end{array}$ \\
\hline 7 & 2.4 & 1 & 1 & 1.05 & 1 & 1.5 \\
\hline 14 & 2.7 & 1.05 & 1.2 & 1.35 & 1.45 & 1.6 \\
\hline 21 & 2.75 & 1.25 & 1.3 & 1.65 & 1.9 & 1.8 \\
\hline 28 & 3.8 & 1.5 & 1.5 & 2 & 2.7 & 2 \\
\hline AVERAGE STRENGTH & 2.91 & 1.2 & 1.25 & 1.51 & 1.76 & 1.73 \\
\hline
\end{tabular}

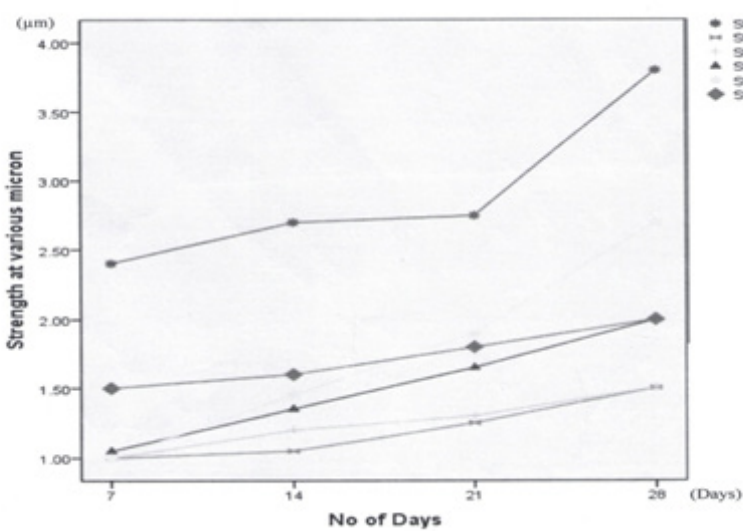

Figure 1: A graph of strength at various portee sizes.

A graph of strength at various portee size of 75 micron, 150 micron, 212 micron, 300 micron, 425 micron and 600 micron against number of days of 7 days, 14 days, 21 days and 28 days. Indicating that 75 micron has the optimal strenght [18] (Figure 1).

\section{Strength at Various Pozzolan}

The result of the different mixed ratio of pozzolan at $0 \%$ $5 \%, 10 \%, 20 \%$, and $30 \%$. Cast and cured for 7 days, 14 days, 21 days and 28 days and also tested with help of a compression test machine is shown in Table 4 below.

Table 4: Mixed Ratio of Pozzolan.

\begin{tabular}{|c|c|c|c|c|c|}
\hline No. of days & $\begin{array}{c}\text { Strength at Pozzolan } \\
\mathbf{0 \%}\end{array}$ & $\begin{array}{c}\text { Strength at Pozzolan } \\
\mathbf{5 \%}\end{array}$ & $\begin{array}{c}\text { Strength at Pozzolan } \\
\mathbf{1 0 \%}\end{array}$ & $\begin{array}{c}\text { Strength at Pozzolan } \\
\mathbf{2 0 \%}\end{array}$ & $\begin{array}{c}\text { Strength at Pozzolan } \\
\mathbf{3 0 \%}\end{array}$ \\
\hline 7 & 1.55 & 2.8 & 3.75 & 4.5 & 4.9 \\
\hline 14 & 1.95 & 3.5 & 4.2 & 6.15 & 5.25 \\
\hline 21 & 2.4 & 4.25 & 4.25 & 7.65 & 5.7 \\
\hline 28 & 3 & 4.5 & 4.5 & 9.8 & 6.15 \\
\hline AVERAGE STRENGTH & 2.23 & 3.76 & 4.18 & 7.03 & 5.5 \\
\hline
\end{tabular}

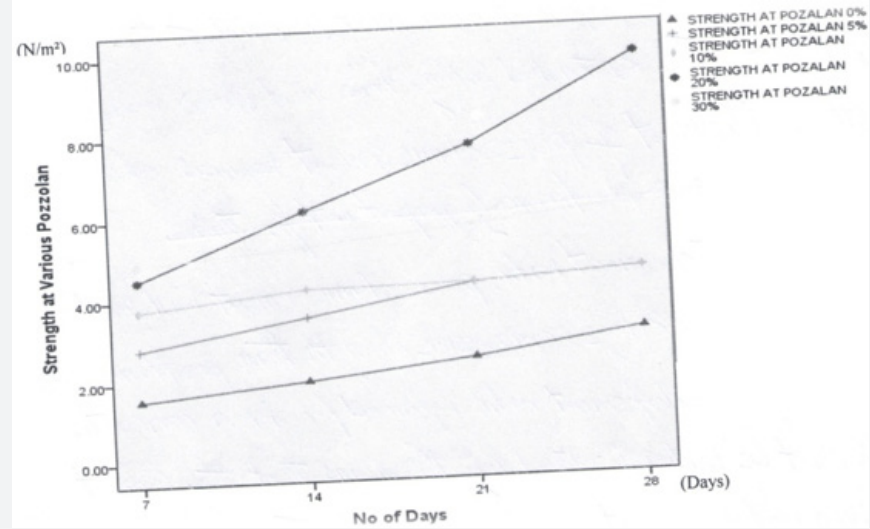

Figure 2: Graph Showing Strength at Various Pozzolan against Number of Days. 


\section{Civil Engineering Research Journal}

A graph of strength at various pozzolan of $0 \%, 5 \%, 10 \%, 20 \%$, and $30 \%$. Against a number of days of 7 days, 14 days, 21 days and 28 days. Indicating that pozzolan at $20 \%$ has the optimal strength [19-22] (Figure 2).

\section{Discussion}

The ashes heated at 5000C were milky white in colour indicating that there is no un-burnt carbon present. The ashes were sieve with different sieve sizes with the help of a sieving machine. Sieve analysis was carried out, and a graph was plotted indicating that the particles size were coarse grains. The result of the ratio mixed for 5\%, 10\%, 20\%, and 30\% Pozzolan indicated that $20 \%$ ratio has the optimum strength while the result of 600 microns, 425 microns, 300 microns, 212 microns, 150 microns and 75 microns indicated that the 75 micron has the optimum strength. Correctly proportioned Pozzolanic cement concrete is suitable for most forms of general construction but, as with all concretes, proper attention must be paid to the curing process. The extended setting time and slow early strength development of pozzolanic cement require extended curing times [22-25].

For a given water/cement ratio, pozzolanic cement will produce a significantly lower 28 days compressive strength than Portland cement. Therefore, the free water/cement ratio required for given concrete strength must be reduced. Effectively, this means that the cement content for given water content should be increased. Typically around 30\% more cement would be required for 16/20 concrete when compared with Portland cement. The $\mathrm{XRF}$ analysis indicated 20 elements, which are as follows; $\mathrm{Mg}, \mathrm{Si}, \mathrm{P}$, $\mathrm{Ca}, \mathrm{Ti}, \mathrm{V}, \mathrm{Cr}, \mathrm{Mn}, \mathrm{Fe}, \mathrm{Ni}, \mathrm{Zn}, \mathrm{Rb}, \mathrm{Sr}, \mathrm{Y}, \mathrm{Zr}, \mathrm{Ru}, \mathrm{Ba}$, and Eu. In all showed that Si with $81.8 \%$ contains the highest percentage of silica. The main impurities include P(5.48\%), Ka (3.19\%) and Ca (1.80\%). The result of XRD analysis showed a low peak intensity for the quartz primary. Therefore, rice husk as an agricultural waste can be converted into valuable product which has so many industrial and domestic applications.

\section{Conclusion}

Pozzolan produced from rice husk ash (RHA) is coarse grains material. The concrete Mixed and cured for different days showed that $20 \%$ Pozzolan and 75 micron has the optimum strength. Strength the experimental result revealed that salaamed RHA could be used as substitutes of cement provided that these materials are processed properly with the maintenance of high fineness and with the use of a chemical activator. The physical and chemical test result of the selected Pozzolanic material from Obubra, Ogoja and Bekwara contain a high amount of silica and sufficient amount of the major oxides; however, they perform credibly as an alternative binder in the presence of chemical activator NADH.

\section{Recommendation}

Pozzolan produced from rice husk ash (RHA) is recommended to develop low-cost building material in order that more of the lower - income sector of developing countries may obtain adequate housing, and to develop lime- Pozzolan cement (LPC) AND LPC- based building material for construction of low-cost housing for the poor.

\section{References}

1. Real C (1996) Determination of silica from Rice husk ash.

2. Adylov GY, Faizeiv SH, Paizullakuhanon M, Mukhsimov S, Nodirmatov E (2003) Silicon Carbide Material obtained from Rice Husk. Technical Physics Letters 29(3): 221-223.

3. Patil SS, Patil BP (2015) Evaluation of mechanical properties of Rice Husk Ash concrete for M256 rave: International Journal of cement Engineering and Technology.

4. Kalapathy U, Proctor A, Shultz J (2000) Production and Properties of Flexible Sodium Silicate Films from Rice Hull Ash. Bio-resources Tech 72(2): 99-106.

5. Joseph S, Baweja D, Crookham GD, Cook DJ (1989) Production and utilization of Rice Husk Ash Preliminary Investigations. Third CANMET/ACI International Conference ON Fly Ash, Silica Feume, Slag and Natural Pozzolanas.

6. Kartini K (2011) Rice Husk Ash-Pozzolanic Material for Sustainability. International Journal of Applied Science and Technology 1(6).

7. Omatola KM, Onojah AD (2012) Rice Husk Ash Potential of High Technological Raw Materials. Journal of Physical Science and Innovation.

8. Nelson Semaan (1986) Mix design of rice husk ash concrete: an Australian experience. University of Wollongong Thesis collection.

9. Chaiyasena T (1992) A study of Properties of High Concrete made from Portland cement containing rice husk ash, fly ash and Superplasticizer. M. Eng. Thesis, Khonkaen University, Thailand.

10. Confidential Report (1998) Rice Husk Ash Market Assessment Bangkok, Thailand.

11. Gidde MR, Jivani AP (2007) Waste to Wealth-Potential of Rice Husk in India a Literature Review. Proceedings of the International Conference on Cleaner Technologies and Environmental management PEC, Pondicherry. India.

12. Harold Watkinson (2002) Personal Communication, CORUS Teeside Technology Centre.

13. Helen Muga, Kriten Betz, James Walter, Curtis Pranger, Andrew Vidor (2005) Development of Appropriate and Sustainable Construction Materials. Civil and Environmental Engineering Sustainable Futures Institute, Michigan Technology University.

14. Camiguing JR, Branzuela Alferg LC, Mark Gerald PadelVisdto (2002) International Iron and Steel Institute.

15. Kalapathy U, Proctor A, Shultz J (2000 b) A simple Method for Production of Pure Rice Hull Ash. Bio-resources Tech 73(3): 257-262.

16. Nnamdi OP (2011) Low Cost Materials for Building and Construction: A case sdtudy of Rice Husk Journal of Sustainable Development and Environmental Pollution 1(1): 87-93.

17. Omatola KM (2009) Instrumental Analysis of Rice Husk Ash Unpublished MSc Project. Department of Physics, University of Agriculture, Markudi, Nigeria.

18. Omatola KM, Onojah AD (2009) Elemental Analysis of RHA using X-ray Fluorescence Technique. INternastional Journal of Physical Science 4(4): 189-193.

19. Omoniyi TE, Akinyemi BA, Olusoji AO (2013) Development of bamboorice husk ash cement mixture for livestock house roofing sheets. American Journal of Scientific and Industrial Research 4(2): 201-209. 


\section{Civil Engineering Research Journal}

20. Oyetola EB, Abdullahi M (2006) The use of Rice Husk Ash in Low-Cost Sand Crete Block production. Department of Civil Engineering, Federal University of Technology, P.M.B.65, Minna, Nigeria.

21. Ramezanianpour AA, Mahdi MK, Ahmadibeni G (2009) The Effect of Rice Husk Ash on Mechanical Properties and Durability of Sustainable Concretes. International Journal of Civil Engineering 7(2): 83-91.

22. Rice husk could nourish Silicon Valley (1994) Science News, 57(11) 194.

23. Rice Husk Ash Market Study (2003).
This work is licensed under Creative Commons Attribution 4.0 License DOI: 10.19080/CERJ.2018.06.555681
24. Suleiman Y, Aigbodion V, Shuaibu L, Shangalo M (2013) Development of Eco-Friendly particleboard Composites using Rice Husk Particle and Gum Arabic.

25. Velupillai L, Mahin DB, Warshaw JW, Wailes EJ (1997) A study of the market for Rice Husk to Energy Systems and Equipment. Louisiana State University Agriculture Center, USA.

\section{Your next submission with Juniper Publishers will reach you the below assets}

- Quality Editorial service

- Swift Peer Review

- Reprints availability

- E-prints Service

- Manuscript Podcast for convenient understanding

- Global attainment for your research

- Manuscript accessibility in different formats

( Pdf, E-pub, Full Text, Audio)

- Unceasing customer service

Track the below URL for one-step submission https://juniperpublishers.com/online-submission.php 